Vol. 1, No. 1, 2019

\title{
PENGARUH MODEL BLENDED LEARNING MENGGUNAKAN SCHOOLOGY TERHADAP PRESTASI BELAJAR DITINJAU DARI KEMANDIRIAN BELAJAR SISWA
}

\author{
Siti Farhatus Tsaniyah ${ }^{1}$, Hena Dian $\mathrm{Ayu}^{2}$, Hestiningtyas Yuli Pratiwi ${ }^{3}$ \\ Pendidikan Fisika, Universitas Kanjuruhan Malang ${ }^{1,2,3}$ \\ farhatusaniya@gmail.com ${ }^{1}$, henadian@unikama.ac.id ${ }^{2}$, hesti@unikama.ac.id ${ }^{3}$
}

\begin{abstract}
Abstrak. Penelitian ini bertujuan mengetahui apakah ada perbedaan prestasi belajar pada siswa yang memiliki kemandirian belajar tinggi antara yang belajar menggunakan model blended learning dan model pembelajaran konvensional. Jenis penelitian yang digunakan adalah kuasi eksperimen dengan rancangan penelitian posttest only control group design. Populasi pada penelitian ini adalah siswa kelas XI MIPA MAN Baureno Bojonegoro dan sampelnya yaitu kelas XI-MIPA 3 sebagai kelas eksperimen dan kelas XI MIPA 2 sebagai kelas kontrol. Data dianalisis menggunakan anova dua jalur. Hasil penelitian menunjukkan bahwa nilai sig 0,045 $\leq 0,05$, artinya ada perbedaan prestasi belajar pada siswa yang memiliki kemandirian belajar tinggi antara yang belajar menggunakan model blended learning dan model pembelajaran konvensional. Dengan demikian, siswa dengan kemandirian tinggi yang mengikuti blended learning menggunakan scholoogy cenderung belajar lebih baik dan akan senantiasa bersaing untuk menunjukkan hasil yang terbaik.
\end{abstract}

Kata Kunci: Blended Learning; Schoology; Prestasi Belajar; Kemandirian Belajar

\section{PENDAHULUAN}

Fisika merupakan salah satu cabang ilmu sains yang menjadi dasar perkembangan teknologi maju dan konsep hidup harmonis dengan alam. Tidak dapat diingkari bahwa pengetahuan tentang seluk-beluk dalam teknologi yang berdasar pada fisika merupakan bagian yang nyata dalam kemakmuran masyarakat. Senada dengan itu Abruscato dalam Zainuddin menyatakan bahwa teknologi adalah penggunaan sains dalam memecahkan masalah-masalah yang dihadapi manusia [1].

Dalam belajar fisika siswa diajak untuk berpikir bagaimana menyelesaikan persoalan yang dikaitkan dengan teori. Pembelajaran fisika seharusnya dapat memberikan pengalaman langsung pada siswa sehingga menambah kemampuan dalam mengkonstruksi, memahami, dan menerapkan konsep yang telah dipelajari [2]. Masalah klasik yang sering dijumpai para guru fisika di sekolah selama ini yaitu semangat belajar siswa dalam mengikuti pelajaran fisika di sekolah tidak seperti mengikuti pelajaran lainnya. Menurut pendapat para mahasiswa mereka mengganggap fisika itu sulit dan hanya hafalan rumus, serta jauh dari aplikasi sehari-hari [3]. Hal ini menyebabkan rasa tanggung jawab serta rasa percaya diri siswa (yang mana ini merupakan sikap dalam kemandirian belajar) dalam mengerjakan persoalan pada mata pelajaran fisika kurang optimal sehingga berpengaruh terhadap rendahnya prestasi belajar siswa [4]. Untuk menyelesaikan persoalan fisika yang umumnya dipelajari melalui pendekatan matematis maka diperlukan suatu usaha dalam pemecahan masalah secara mandiri sehingga memberikan suatu pengalaman kongkrit yang akan memberikan makna tersendiri bagi peserta didik. Sebagaimana dikemukakan Sudjana bahwa prestasi belajar siswa di sekolah 30\% dipengaruhi oleh lingkungan dan $70 \%$ dipengaruhi oleh kemampuan siswa.

Faktor kemampuan siswa tersebut di antaranya adalah kemampuan dalam belajar mandiri atau kemandirian belajar. Kemandirian belajar sangat penting dimiliki oleh individu dalam proses 
pembelajaran. Didukung oleh Keegan bahwa kemandirian dalam belajar ini perlu diberikan kepada peserta didik supaya mereka mempunyai tanggung jawab dalam mengatur dan mendisiplinkan dirinya dan dalam mengembangkan kemampuan belajar atas kemauan sendiri. Tuntutan kemandirian belajar tersebut akan semakin kuat dengan pemanfaatan teknologi informasi dan komunikasi dalam pembelajaran fisika, yaitu pembelajaran melalui internet atau blended learning. Menurut Rahayu \& Nuryata dalam Hermawanto dkk bahwa pembelajaran blended mengkombinasikan metode pendidikan konvensional (tatap muka) dengan pembelajaran yang ditunjang dengan adanya teknologi [5]. Blended learning melibatkan siswa dalam pembelajaran online diluar kelas dalam siswa mengakses pemberian materi, sedangkan pada pertemuan tatap muka siswa dapat mengajukan pertanyaan tentang hal yang belum dimengerti saat pembelajaran online berlangsung. Berbagai macam media dan teknologi dapat dimanfaatkan untuk mengkombinasikan pembelajaran tatap muka. Salah satu media online yang bisa digunakan dalam pembelajaran adalah schoology. Schoology yaitu aplikasi yang menggabungkan jejaring sosial dan LMS. Putri dkk menjelaskan bahwa schoology merupakan salah satu LMS berbentuk web sosial yang menawarkan pembelajaran sama seperti di dalam kelas secara gratis dan mudah digunakan seperti media sosial facebook [6].

Kelebihan dari schoology menurut Amiroh dalam Hasanah dkk yaitu pada schoology tersedia fasilitas attandance yang digunakan untuk mengecek kehadiran siswa, dan juga fasilitas analityc untuk melihat semua aktivitas siswa pada setiap course, assignment, discussion dan aktivitas lain yang kita siapkan untuk siswa [7]. Dengan memanfaatkan teknologi, guru dapat meningkatkan efektivitas dan efisiensi pembelajaran. Adapun bagi siswa, penggunaan teknologi dapat memberikan kesempatan belajar yang lebih berkualitas [8]. Model pembelajaran berbasis online memang sangat dibutuhkan oleh mahasiswa dalam rangka meningkatkan penguasaan materi perkuliahan [9]. Sejalan dengan itu, Mekhlafi menyatakan bahwa pemanfaatan teknologi komunikasi dan informasi dalam pembelajaran memiliki dampak positif terhadap performansi dan prestasi belajar peserta didik [10]. Berdasarkan uraian di atas, peneliti tertarik untuk mengkaji mengenai upaya untuk menggabungkan kegiatan belajar konvensional (tatap muka) dengan e-learning menggunakan schoology dan dengan memperhatikan faktor internal siswa yaitu kemandirian belajar yang mana sikap-sikap didalamnya merupakan faktor-faktor yang mempengaruhi prestasi belajar.

Blended learning merupakan istilah yang berasal dan bahasa Inggris yang tendiri dan dua suku kata, blended dan learning. Blended artinya campuran atau kombinasi yang baik. Blended learning merupakan suatu upaya untuk menggabungkan kegiatan belajar konvensional (tatap muka) dengan belajar menggunakan komputer atau perlengkapan elektronik berdasarkan petunjuk dan pendidik di mana materi dapat berbentuk media digital yang digunakan untuk membantu proses belajar-mengajar konvensional [11]. Menurut Rovai \& Jordan model blended learning pada dasarnya merupakan gabungan keunggulan pembelajaran yang dilakukan secara tatap muka (face-toface learning) dan secara virtual (e-learning).

Penggunaan model blended learning menurut Husamah dibutuhkan pada saat terjadi situasi dan kondisi sebagai berikut: (1) proses belajar mengajar tidak hanya tatap muka, namun menambah waktu pembelajaran dengan memanfaatkan teknologi dunia maya; (2) mempermudah dan mempercepat proses komunikasi non-stop antara pengajar dan peserta didik; (3) peserta didik dan pendidik dapat diposisikan sebagai pihak yang belajar; dan (4) membantu proses percepatan pengajaran [11].

Untuk mengembangkan blended learning, Carmen dalam Syarif menyebutkan ada lima kunci dalam mengembangkan blended learning tersebut. Pertama adalah live event, yaitu pembelajaran langsung atau tatap muka yang berlangsung dalam waktu dan tempat yang sama (ruang kelas). Kedua adalah pembelajaran mandiri yang memungkinkan siswa belajar kapan 
saja dan dimana saja. Ketiga adalah kolaborasi, baik kolaborasi antar teman atau pengajar melalui alat komunikasi seperti forum diskusi/chatroom di schoology. Keempat adalah asessment yaitu cara mengukur keberhasilan dalam proses pembelajaran baik online maupun offline. Kelima adalah pendukung kinerja (performance support materials) untuk mengkombinasikan pembelajaran tatap muka [12].

Schoology adalah sebuah situs yang menggabungkan fitur jejaring sosial dan LMS [13]. Melalui schoology, kita bisa berinteraksi sosial sekaligus belajar. Schoology juga mudah diakses dari perangkat mobile. Aplikasi ini dapat mudah ditemukan di pasar aplikasi untuk Apple iOS dan Android ponsel. Penyelesaian tugas menulis yang besar akan menjadi penghalang pada perangkat, namun peserta didik dapat memeriksa pandangan tugas, menavigasi isi kursus, meninjau nilai mereka, melihat kalender dari tugas yang akan datang, dan berkomunikasi dengan instruktur. Schoology adalah sebuah sistem pembelajaran online yang mengizinkan pendidik mengelola pembelajaran, melibatkan para siswa, dan berbagi materi.

Prestasi belajar adalah hasil yang diperoleh berupa kesan-kesan yang mengakibatkan perubahan dalam diri individu sebagai hasil dari aktivitas dalam belajar. Istilah "prestasi belajar" (achievement) berbeda dengan "hasil belajar" (learning outcome). Prestasi belajar pada umumnya berkenaan dengan aspek pengetahuan, sedangkan hasil belajar meliputi aspek pembentukan watak peserta didik [14]. Perubahan tingkah laku sebagai hasil yang dicapai yang berwujud prestasi belajar dapat dipengaruhi oleh beberapa faktor, diantaranya yaitu faktor dari dalam berkaitan dengan segala yang berhubungan dengan diri siswa itu sendiri berupa motivasi, minat, bakat, kepandaian, sikap, perasaan dan faktor pribadi lainnya yang dan faktor dari luar berhubungan dengan pengaruh yang datang dari luar diri individu berupa sarana dan prasarana, lingkungan, masyarakat, dan lain sebagaianya.

Kemandirian adalah hal/keadaan dapat berdiri sendiri tanpa bergantung pada orang lain. Menurut Dimyati sebagaimana yang dikutip oleh Syarif bahwa kemandirian belajar dapat diartikan sebagai aktivitas belajar dan berlangsungnya lebih didorong oleh kemauan sendiri, pilihan sendiri dan tanggung jawab sendiri dari pembelajar [12]. Siswa dikatakan telah mampu belajar secara mandiri apabila telah mampu melakukan tugas belajar tanpa ketergantungan dengan orang lain. Menurut Hidayati \& Listyani bahwa siswa yang memiliki kemandirian belajar mempunyai kecenderungan tingkah laku sebagai berikut: (1) ketidaktergantungan terhadap orang lain, (2) memiliki kepercayaan diri, (3) berperilaku disiplin, (4) memiliki rasa tanggung jawab, (5) berperilaku berdasarkan inisiatif sendiri, dan (6) melakukan kontrol diri [15].

\section{METODE PENELITIAN}

Jenis penelitian ini termasuk kuasi eksperimen (quasi experiment) yang menggunakan posttest only control group design yaitu pemberian tes kepada kedua kelompok dilaksanakan setelah perlakuan atau proses pembelajaran diberikan. pada penelitian ini adalah siswa kelas XI MAN Baureno Bojonegoro tahun pelajaran 2017/2018 yang terdiri dari 3 kelas, yaitu XI-MIPA 1, XI-MIPA 2, dan XI-MIPA 3 yang seluruhnya berjumlah 96 siswa. Sampel pada penelitian ini dipilih berdasarkan teknik purposive sampling, selanjutnya ditentukan kelas XI-MIPA 3 sebagai kelas eksperimen yang terdiri dari 32 siswa belajar menggunakan model blended learning menggunakan schoology dan kelas XI MIPA 2 sebagai kelas kontrol yang terdiri dari 32 siswa belajar menggunakan model pembelajaran konvensional. Instrumen penelitian terdiri dari (1) angket tertutup, yaitu angket untuk mengukur kemandirian belajar yang disusun dengan menyediakan pilihan jawaban sehingga responden (siswa) tinggal memilih yang sesuai dengan keadaan dirinya yang terdiri dari 20 butir pernyataan favorable (positif), dan (2) tes prestasi 
belajar dalam bentuk uraian. Skor maksimal benar untuk jawaban siswa pada soal tes tersebut adalah 5, sedangkan skor untuk jawaban siswa yang salah adalah 0. Sebelum digunakan, instrumen angket kemandirian belajar dan tes prestasi belajar divalidasi oleh dua orang ahli isi (obejctive validity) dan diujicoba untuk menentukan reabilitas, daya beda, dan indek kesukarannya. Berdasarkan hasil validasi menggunakan MS.Excel 2013, 10 soal memiliki thitung lebih besar dari ttabel sedangkan 2 soal memiliki thitung lebih kecil dari ttabel. Hal tersebut menunjukkan bahwa 10 soal dinyatakan valid dan 2 soal tidak valid. Jadi, 10 soal tersebut yang dipakai peneliti sebagai penelitian. Data hasil penelitian dianalisis secara bertahap sesuai dengan fungsi analisis, yaitu sebagai penguji hipotesis. Uji normalitas dan uji homogenitas terhadap data yang akan dianalisis dilakukan sebagai persyaratan untuk uji hipotesis. Uji hipotesis menggunakan ANOVA dua jalur (two way anova).

\section{HASIL DAN PEMBAHASAN}

Data yang dideskripsikan dalam penelitian ini adalah data prestasi belajar fisika hasil posttest yang dilakukan setelah pemberian perlakuan. Data penelitian dikelompokkan menjadi (1) data presatsi belajar siswa yang mengikuti blended learning menggunakan schoology $\left(\mathrm{A}_{1}\right)$, (2) data prestasi belajar siswa dengan kemandirian tinggi yang mengikuti blended learning $\left(A_{1} B_{1}\right)$, (3) data prestasi belajar siswa dengan kemandirian rendah yang mengikuti blended learning $\left(\mathrm{A}_{1} \mathrm{~B}_{2}\right)$, (4) data prestasi belajar siswa yang mengikuti model pembelajaran konvensional $\left(\mathrm{A}_{2}\right)$, (5) data prestasi belajar siswa dengan kemandirian tinggi yang mengikuti pembelajaran konvensional $\left(\mathrm{A}_{2} \mathrm{~B}_{1}\right)$, dan (6) data prestasi belajar siswa dengan kemandirian rendah yang mengikuti pembelajaran konvensional $\left(\mathrm{A}_{2} \mathrm{~B}_{2}\right)$. Rekapitulasi tentang data hasil belajar pada pembelajaarn blended dan konvensional disajikan dalam Tabel 1.

Tabel 1. Rerata dan Standar Deviasi Kelompok Perlakuan

\begin{tabular}{ccccc}
\hline $\begin{array}{l}\text { Kelomp } \\
\text { ok }\end{array}$ & $\begin{array}{l}\text { Mea } \\
\text { n }\end{array}$ & $\begin{array}{c}\text { Std. } \\
\text { Deviation }\end{array}$ & $\begin{array}{c}\text { Skor } \\
\text { max }\end{array}$ & $\begin{array}{c}\text { Skor } \\
\text { min }\end{array}$ \\
$\mathrm{A}_{1}$ & 73 & 11,8 & 97 & 43 \\
$\mathrm{~A}_{2}$ & 68 & 11,6 & 90 & 37 \\
$\mathrm{~A}_{1} \mathrm{~B}_{1}$ & 82 & 6,2 & 97 & 73 \\
$\mathrm{~A}_{1} \mathrm{~B}_{2}$ & 65 & 9,9 & 80 & 43 \\
$\mathrm{~A}_{2} \mathrm{~B}_{1}$ & 78 & 4,5 & 90 & 73 \\
$\mathrm{~A}_{2} \mathrm{~B}_{2}$ & 62 & 10,0 & 77 & 37 \\
\hline
\end{tabular}

Tabel 1 menunjukkan bahwa rerata prestasi belajar kelompok siswa yang mengikuti blended learning $\left(\mathrm{A}_{1}\right)$ lebih tinggi dari yang mengikuti pembelajaran konvensional $\left(\mathrm{A}_{2}\right)$, tetapi standard deviasinya tidak jauh berbeda. Tabel 1 juga menunjukkan bahwa rerata prestasi belajar kelompok siswa dengan kemandirian tinggi yang mengikuti blended learning $\left(\mathrm{A}_{1} \mathrm{~B}_{1}\right)$ paling tinggi dibandingkan dengan kelompok yang lainnya.

Sebelum data yang diperoleh digunakan untuk menguji hipotesis, maka dilakukan uji normalitas dan homogenitas. Berdasarkan data hasil uji normalitas dan homogenitas menunjukkan bahwa nilai signifikansi $\geq 0,05$, sehingga data berdistribusi norma dan varian homogen sehingga uji anova dua jalur dapat dilanjutkan. Ringkasan hasil uji ANOVA disajikan dalam Tabel 2. 
Tabel 2. Hasil Analisis Uji Anova Dua Jalur Berdasarkan Tabel Contrast Results (K Matrix)

\begin{tabular}{cc}
\hline Simple contras & sig \\
Model Pembelajaran & 0,045 \\
(Sumber: hasil data diolah SPSS versi 22.00 for windows)
\end{tabular}

Hasil analisis data model pembelajaran pada tabel 4. diatas menunjukkan nilai sig $0,045 \leq$ 0,05 , artinya $\mathrm{H}_{0}$ ditolak atau Ha diterima. Sehingga ada perbedaan prestasi belajar pada siswa yang memiliki kemandirian belajar tinggi antara yang belajar menggunakan model blended learning dan model pembelajaran konvensional. Hal tersebut dapat dilihat pada rata-rata nilai prestasi belajar siswa yang menggunakan model blended learning dengan kemandirian belajar tinggi sebesar 82, sedangkan rata-rata nilai prestasi belajar siswa yang belajar siswa yang menggunakan model pembelajaran konvensional dengan kemandirian belajar tinggi sebesar 78 .

Tahap self-paced learning memungkinkan siswa berkemandirian tinggi pada kelas blended learning dapat belajar kapan saja dan dimana saja menggunakan bahan ajar dan video yang telah di upload di schoology sebagai bahan diskusi sehingga siswa dapat mengontrol diri, memiliki rasa tanggung jawab dan berperilaku disiplin. Dengan media schoology tersebut pada tahap assesment menunjukkan nilai yang bertambah dengan keadaan diri siswa tanpa dipengaruhi oleh temannya atau tidak tergantung orang lain dan berdasarkan inisiatif sendiri akan berbeda dengan siswa berkemandirian tinggi yang belajar menggunakan model pembelajaran konvensional. Pada pembelajaran konvensional, kegiatan pembelajaran lebih berpusat pada guru, inisiatif siswa akan terbelenggu, persaingan antar siswa untuk menunjukkan hasil terbaik kurang mendapat ruang dalam pembelajaran. Siswa berkemandirian tinggi pada kelas konvensional saat pemberian tugas rumah, masih ada beberapa siswa yang menyelesaikan di sekolah dengan cara melihat pekerjaan teman yang sudah selesai. Sehingga setelah diberikan tes ulangan tertulis oleh guru diperoleh hasil belajar kognitif siswa yang kurang menggembirakan [16]. Hal ini sejalan dengan penelitian Sandi yang menyatakan bahwa siswa dengan kemandirian tinggi pada pembelajaran dengan blended learning menjadi sangat mendukung proses pembelajaran [17]. Siswa dengan kemandirian tinggi, yang mengikuti blended learning akan senantiasa bersaing untuk menunjukkan hasil yang terbaik. Hal ini akan bermuara pada prestasi belajar yang optimal. individu yang memiliki kemandirian belajar yang tinggi cenderung belajar lebih baik, mampu memantau, mengevaluasi, dan mengatur belajarnya secara efektif; menghemat waktu dalam menyelesaikan tugasnya, mengatur belajar dan waktu secara efisien, dan memperoleh skor yang lebih tinggi dalam pelajaran sains [18]. Temuan lain juga menyatakan bahwa mahasiswa yang berprestasi tinggi pada umumnya mampu mengatur dirinya sendiri dalam aktivitas belajarnya [19].

\section{PENUTUP}

Simpulan yang dapat diambil dari penelitian ini yaitu siswa dengan kemandirian tinggi yang mengikuti blended learning menggunakan scholoogy cenderung belajar lebih baik, mampu memantau, mengevaluasi, dan mengatur belajarnya secara efektif; menghemat waktu dalam menyelesaikan tugasnya, mengatur belajar dan waktu secara efisien, dan akan senantiasa bersaing untuk menunjukkan hasil yang terbaik. Hal ini berdasarkan data yang diperoleh dari hasil penelitian yang telah dilakukan, bahwa ada perbedaan prestasi belajar pada siswa yang memiliki kemandirian belajar tinggi antara yang belajar menggunakan model blended learning dan model pembelajaran 
konvensional. Ini berarti, peningkatan kemandirian siswa adalah suatu yang kritikal dalam meningkatkan prestasi belajar yang perlu menjadi perhatian guru dan peneliti.

\section{DAFTAR PUSTAKA}

Zainuddin, Analisis Karakteristik Umum Materi Ajar fisika Serta Strategi Belajar dan Pembelajarannya, Paradigma, Jurnal Pendidikan Mipa, vol. 1, no.1, 2007, Hlm. 65-72.

[2] Nuraeni, S. D, Peningkatan Kemandirian Belajar Ipa Melalui Pembelajaran Kooperatif Tipe Group Investigation (Gi) Di Kelas VIII SMP Negeri 33 Purworejo Tahun Pelajaran 2011/2012, Radiasi, vol.1, no.1, 2012, Hlm. 15-18

[3] H. D. Ayu, A. Jufriadi, Pengaruh penerapan strategi open ended problem bersetting kooperatif terhadap kemampuan menyelesaikan masalah ditinjau dari kreativitas siswa SMP PGRI 6 Malang, JIP, vol.7, no. 1, 2017, Hlm. 1-6

[4] H. Y. Pratiwi, H. D, Ayu, Pengembangan bahan ajar problem solving disertai isomorphic problem pairs sebagai solusi untuk meningkatkan kemampuan berpikir kritis mahasiswa, Seminar Nasional Hasil Penelitian Universitas Kanjuruhan Malang, 2017, Hlm. 342-350

[5] Hermawanto, Kusairi, S, dan Wartono, Pengaruh Blended Learning terhadap Penguasaan Konsep dan Penalaran Fisika Peserta Didik Kelas X, Jurnal Pendidikan Fisika Indonesia, 9, 2013, Hlm. 67-76.

[6] Putri, N. W., Jampel, N., dan Suartama, I. K, Pengembangan E-Learning Berbasis Schoology pada Mata Pelajaran IPA Kelas VIII di SMP Negeri 1 Seririt, Journal Edutech Universitas Pendidikan Ganesha Jurusan Teknologi Pendidikan, vol. 2, no. 1, 2014.

[7] Hasanah, N., Suyanto, E., dan Suana, W, E-Learning dengan Schoology Sebagai Suplemen Pembelajaran Fisika Materi Elastisitas dan Hukum Hooke, Jurnal Pembelajaran Fisika, vol 4, no 2, 2016, Hlm. 71-81.

[8] H. D. Ayu, H. Y. Pratiwi, S.K, dan Muhardjito. Pengembangan E-Scaffolding untuk Meningkatkan Kualitas Proses dan Hasil Belajar. Jurnal Kependidikan, vol. 1, no. 2, 2017, Hlm. 334-347.

[9] H. Y. Pratiwi, C. S, Pengembangan Model Perkuliahan Berbasis On-Line untuk Menunjang Pembelajaran Matakuliah Telaah Kurikulum Pendidikan Fisika, Prosiding Seminar Nasional Penelitian 2015 LPPM Universitas Kanjuruhan Malang, 6 Juni 2015, Hlm. 46-52.

[10] Al-Mekhlafi, A, The Internet and EFL Teaching: The Reactions of UAE Secondary School English Language Teachers, Journial of Language and Learning ISSN 1740 4983, vol. 2, no. 2, 2004, pp. 88-113.

[11] Husamah, S, Pembelajaran Bauran (Blended Learning) Terampil Memadukan Keunggulan Pembelajaran Face-To-Face, E-Learning Offline-Online Dan Mobil Learning, Jakarta: Prestasi Pustaka Publisher, 2014.

[12] Syarif, I, Pengaruh Model Blended Learning terhadap Motivasi dan Prestasi Belajar Siswa SMK, Jurnal Pendidikan Vokasi, vol. 2, no. 2, 2012, Hlm. 234-248. 
[13] Fatur, Schoology jejaring sosial yang sangat bermanfaat bagi guru dan siswa, 2013. Website: http://fatkoer.wordpress.com, diakses pada tanggal 23 Desember 2017

[14] Arifin, Z. Evaluasi Pembelajaran. Bandung: Pt Remaja Rosdakarya, 2016.

[15] Hidayati, K., dan Listyani, E, Pengembangan Instrumen Kemandirian Belajar Mahasiswa, Jurnal Penelitian Dan Evaluasi Pendidikan, vol. 14, no. 1, 2010.

[16] S. Rijal, S. Bachtiar, Hubungan antara Sikap, Kemandirian Belajar, dan Gaya Belajar dengan Hasil Belajar Kognitif Siswa, Jurnal BIOEDUKATIKA, vol. 3, no. 2, 2015, ISSN: 2338-6630, Hlm. 15-20.

[17] Sandi, G, Pengaruh Blended Learning terhadap Hasil Belajar Kimia Ditinjau dari Kemandirian Siswa, Jurnal Pendidikan Dan Pengajaran, jilid 45, no. 3, 2012, Hlm. 241251.

[18] T.Jumaisyaroh, E.E. Napitupulu dan Hasratuddin, Peningkatan Kemampuan Berpikir Kritis Matematis Dan Kemandirian Belajar Siswa Smp Melalui Pembelajaran Berbasis Masalah, Jurnal Admathedu, vol. 5, no. 1, 2015, ISSN: 2088-687X, Hlm. 87-106.

[19] Paris, S. G. and Paris, A. H, Classroom Applications of Research on Self-Regulated Learning, Educational Psychologist, 36, 2001, pp. 89-91. 